\title{
Community structure of metazoan parasites of silverside, Odontesthes bonariensis (Pisces, Atherinopsidae) from Argentina
}

\author{
Fabiana B. Drago
}

Laboratorio de Helmintología, División Zoología Invertebrados, Museo de La Plata, Facultad de Ciencias Naturales y Museo, Paseo del Bosque s/n, 1900 La Plata, Buenos Aires, Argentina. (fdrago@fcnym.unlp.edu.ar)

\begin{abstract}
The helminth communities of silverside, Odontesthes bonariensis (VALENCIENNES, 1835), from two Argentinean lagoons were studied and compared at component community and infracommunity levels. Nine helminth species were found: five digeneans (Austrodiplostomum cf. mordax, Ascocotyle (Phagicola) cf. diminuta, Ascocotyle sp., Thometrema bonariensis and Saccocoelioides sp.); two nematodes (Contracaecum sp. and Hysterothylacium sp.); one acanthocephalan (Wolffhugelia matercula) and one cestode (Cangatiella macdonaghi). Odontesthes bonariensis is a new host record for five parasite species. Richness, diversity and number of helminths in silversides from Salada Grande lagoon were higher than in those from Lacombe lagoon. This could be related with lagoon size, abundance of mollusks and fish-eating birds, and size and diet of silversides captured in each lagoon. In Salada Grande lagoon the helminth community of silversides was dominated by the allogenic and generalist species $A$. cf. mordax; while the autogenic and intermediate specialist species C. macdonaghi was dominant in Lacombe lagoon. Host sex did not affect richness, diversity or total abundance, whereas host size was positively correlated with these attributes, except diversity in Salada Grande lagoon.
\end{abstract}

KEYWORDS. Helminth community, infracommunity, Platyhelminthes, Nematoda, Acanthocephala.

RESUMEN. Estructura de la comunidad de metazoarios parazitos del pejerrey, Odontesthes bonariensis (Pisces, Atherinopsidae) from Argentina. Las comunidades de helmintos del pejerrey, Odontesthes bonariensis (VALENCIENNES, 1835), procedentes de dos lagunas argentinas fueron estudiadas y comparadas a nivel de comunidad componente e infracomunidad. Se hallaron nueve especies de helmintos, cinco digeneos (Austrodiplostomum cf. mordax, Ascocotyle (Phagicola) cf. diminuta, Ascocotyle sp., Thometrema bonariensis y Saccocoelioides $\mathrm{sp}$.); dos nematodes (Hysterothylacium sp. y Contracaecum sp.); un acantocéfalo (Wolffhugelia matercula) y un cestode (Cangatiella macdonaghi). Odontesthes bonariensis es reportado como un nuevo hospedador para cinco de estas especies. La riqueza específica, la diversidad y la carga parasitaria fueron mas elevadas en la laguna Salada Grande que en la Laguna Lacombe. Esto podría estar relacionado con atributos del cuerpo de agua (tamaño, abundancia de moluscos y aves ictiófagas) y del hospedador (talla y dieta de los pejerreyes capturados en cada laguna). En la laguna Salada Grande, la comunidad de helmintos fue dominada por una especie alogénica y generalista, $A$. cf. mordax; mientras que en la laguna Lacombe fue dominada por un a especie autogénica y especialista intermedia, C. macdonaghi. El sexo del hospedador no estuvo correlacionado con la riqueza específica, diversidad y carga parasitaria, mientras que la talla del hospedador presentó correlación positiva con estos atributos, excepto la diversidad en la laguna Salda Grande.

PALABRAS-CLAVE. Comunidad de helmintos, infracomunidad, Platyhelminthes, Nematoda, Acantocephala.

The silverside, Odontesthes bonariensis (Valenciennes, 1835) is one of the most important freshwater commercial and sport fishing resources in the Pampean region of Argentina. It is the species most used for restocking due to its high adaptability and economic importance, and it has been introduced in numerous freshwater environments in Argentina and other countries (Japan, Italia, Peru, Bolivia and Chile) (Grosman, 2001).

Silversides are zooplanktivores, although capable of exploiting other habitat resources such as insects, mollusks, other invertebrates and fishes, and even cannibalism, when plankton is scarce (EscALANTE, 2001).

Previous surveys of parasites of silversides from Argentina have focused mainly on taxonomy. At present, the records of helminths in this host species consist of metacercariae of Austrodiplostomum mordax Szidat \& Nani, 1951 and Tylodelphys destructor Szidat \& Nani, 1951 (Digenea-Diplostomidae) found in the brain; metacercariae of Heterophyidae (Digenea) in gills; third-stage larvae of Contracaecum sp. (Nematoda-Anisakidae) in the body cavity, adults of Cangatiella macdonaghi (Szidat \& Nani, 1951) (Cestoda-Proteocephalidae) and the monogeneans Dactylogyrus sp. (Dactylogyridae) and Gyrodactylus sp. (Gyrodactyldae) in the intestine (MAC DonaGH, 1932; Szidat \& NANi, 1951; SzIDAT, 1969; Gil de Pertierra \&
ViozZI, 1995; Mancini et al., 2006). A few studies were focused on helminth populations of silverside (MANCINI et al., 2008), however, no previous studies have focused on the parasite communities of this fish species.

The goal of this work is to analyze the helminth community of $O$. bonariensis, at the component and infracommunity levels, in two lagoons from Buenos Aires Province, Argentina.

\section{MATERIALS AND METHODS}

The fish were sampled in two sites in Buenos Aires Province, Argentina: Salada Grande lagoon (SGL), General Lavalle (36 $\left.55^{\circ} \mathrm{S}, 5^{\circ} 58^{\prime} \mathrm{W}\right)$ and Lacombe lagoon (LL), Lezama (3549'S, 5749'W). The SGL has a surface area of 6,078 ha and LL has a surface area of 140 ha. A total of 653 silversides were captured between April 1996 and May 1998; 262 in SGL [fall $1996(n=22)$, winter $1996(n=31)$, spring 1996 $(n=29)$, summer $1997(n=30)$, fall $1997(n=30)$, winter $1997(n=30)$, spring $1997(n=30)$, summer $1998(n=60)]$ and 391 in LL [winter $1996(n=26)$, spring $1996(n=31)$, summer $1997(n=30)$, fall $1997(n=32)$, winter 1997 $(n=29)$, spring $1997(n=65)$, summer $1998(n=94)$, fall $1998(n=84)]$. The fish were captured using coastal net and serial gill-net. Each individual was sexed by direct 
examination of gonads (102 males, 128 females in SGL; 135 males, 117 females in LL; juveniles could not be reliably sexed due to insufficient gonad development) and measured, $3.8-46.8 \mathrm{~cm}(22 \pm 8.8)$ standard length in SGL and 1.7-40.8 cm (16.4 \pm 7.4$)$ in LL. The Student " $t$ " test was used to verify the existence of significant differences among standard length of silversides from both lagoons. The $10 \%$ of the hosts was examined in the field for helminths, which were removed for taxonomic study. The rest of hosts were fixed in formalin $10 \%$, except the specimens larger than $15 \mathrm{~cm}$ of standard length, which were dissected in the field, their heads and viscera were fixed in $10 \%$ formalin and examined in the laboratory. Digeneans, acantocephalans and cestodes were stained with a 1:6 dilution in $96 \%$ ethanol of hydrochloric carmine, dehydrated and mounted in Canada balsam. Nematodes were cleared in lactophenol or glycerine. The helminths studied were deposited in the Helminthological Collection of Museo de La Plata (MLP), La Plata, Argentina (MLP 3977-3985, 40694268, 4374-4549, 4557-4561, 4591-4597, 5286-5287, 5293-5295). The food items were identified under a stereoscopic microscope. The results were expressed as relative frequency of occurrence $(\mathrm{FO}=$ number of samples with occurrence of a given food item / number of samples analyzed).

Ecological terminology follows Bush et al. (1997) and the specificity was classified according to DesDevises et al. (2002). The description of infracommunity structure was based on helminth species richness, mean number of parasites, diversity, evenness, and dominance. Shannon's Diversity Index $(\mathrm{H})$ was calculated using base 10 logarithms, and the BergerParker index of dominance was calculated following MagurRan (1988). All helminth species, irrespective of their rareness in helminth faunas, were considered for the calculation of these attributes. Possible effect of host sex on helminth species richness, diversity and total abundance was assessed using Mann-Whitney test (U), and possible influence of host standard length was tested by Spearman's rank correlation coefficient $\left(r_{s}\right)$. A Kruskal-Wallis test (KW) was used to compare mean values of richness, diversity and number of helminth per infracommunity among seasons. The correlation between standard length of silversides and number of metacercariae of $A$. cf. mordax was tested by Spearman's rank correlation coefficient $\left(\mathrm{r}_{\mathrm{s}}\right)$.

\section{RESULTS}

Composition of the helminth community. Nine species of helminths were found parasitizing $O$. bonariensis, five of them as larval stages. Five species were found in silversides from both lagoons: $A$. cf. mordax, C. macdonaghi, Wolffhugelia matercula Mañé Garzón \& Dei-Cas, 1974 (Acanthocephala-Neoechinorhynchidae), Contracaecum sp. and Hysterothylacium sp. (NematodaAnisakidae). Four species were found exclusively in silversides from SGL: Thometrema bonariensis Lunaschi, 1988(Digenea-Derogenidae), Saccocoelioides sp. (Digenea-Haploporidae), Ascocotyle (Phagicola) cf. diminuta (Stunkard \& Haviland, 1924) and Ascocotyle sp. (Digenea-Heterophyidae). Three digenean species, one nematode species and one acantocephalan species are reported for the first time in O. bonariensis (Tab. I). The highest prevalence values were observed for Ascocotyle sp. and C. macdonaghi in silversides from SGL and LL, respectively; while the most abundant species were A. cf. mordax and C. macdonaghi in SGL and LL, respectively (Tab. II).

Colonization strategy. All helminth species found in this study have complex life cycles with at least

Tab. I. Helminth parasites found in Odontesthes bonariensis from Salada Grande and Lacombe lagoons.

\begin{tabular}{|c|c|c|c|}
\hline & Infection site & $\begin{array}{l}\text { Development } \\
\text { stages }\end{array}$ & Colonization strategy \\
\hline \multicolumn{4}{|l|}{ Digenea } \\
\hline Austrodiplostomum cf. mordax & $\begin{array}{l}\text { brain (meninges, ventricles), } \\
\text { optic nerve and spinal chord. }\end{array}$ & metacercariae & allogenic \\
\hline Ascocotyle (P.) cf. diminuta* & gills & metacercariae & allogenic \\
\hline Ascocotyle sp. & heart (bulbus arteriosus) & metacercariae & allogenic \\
\hline Thometrema bonariensis* & intestine & adults & autogenic \\
\hline Saccocoeliodes sp.* & intestine & immature & autogenic \\
\hline \multicolumn{4}{|l|}{ Cestoda } \\
\hline Cangatiella macdonaghi & intestine & adults & autogenic \\
\hline \multicolumn{4}{|l|}{ Nematoda } \\
\hline Hysterothylacium sp.* & mesentery & $\mathrm{L}_{3}$ & autogenic \\
\hline Contracaecum sp. & mesentery & $\mathrm{L}_{3}$ & allogenic \\
\hline \multicolumn{4}{|l|}{ Acanthocephala } \\
\hline Wolffhugelia matercula* & intestine & immature & autogenic \\
\hline
\end{tabular}

* New host records 
Tab. II. Prevalence (P), mean intensity (IM) and mean abundance (AM) of helminths in Odontesthes bonariensis from Salada Grande and Lacombe lagoons.

\begin{tabular}{|c|c|c|c|c|c|c|}
\hline & \multicolumn{3}{|c|}{$\operatorname{SGL}(n=262)$} & \multicolumn{3}{|c|}{$\operatorname{LL}(\mathrm{n}=391)$} \\
\hline & $\mathrm{P}(\%)$ & IM (range) & $\mathrm{AM}(\mathrm{X} \pm \mathrm{sd})$ & $\mathrm{P}(\%)$ & IM (range) & $\operatorname{AM}(X \pm s d)$ \\
\hline \multicolumn{7}{|l|}{ Digenea } \\
\hline Austrodiplostomum cf. mordax & 62 & $184(1-1871)$ & $114 \pm 276$ & 24 & $60(1-481)$ & $14.3 \pm 49$ \\
\hline Ascocotyle (P.) cf. diminuta & 89 & $17.4(1-66)$ & $15 \pm 13$ & - & - & - \\
\hline Ascocotyle sp. & 98 & $7.6(1-25)$ & $7.5 \pm 5.7$ & - & - & - \\
\hline Thometrema bonariensis & 2.3 & $4.7(1-8)$ & $0.11 \pm 0.8$ & - & - & - \\
\hline Saccocoeliodes sp. & 0.8 & $47(2-92)$ & $0.36 \pm 5.7$ & - & - & - \\
\hline \multicolumn{7}{|l|}{ Cestoda } \\
\hline Cangatiella macdonaghi & 61 & $152(1-3387)$ & $94 \pm 304$ & 50 & $78(1-1606)$ & $39 \pm 127$ \\
\hline \multicolumn{7}{|l|}{ Nematoda } \\
\hline Hysterothylacium sp. & 2.3 & $1(1-1)$ & $0.02 \pm 0.1$ & 2 & 1.1 & $0.02 \pm 0.17$ \\
\hline Contracaecum sp. & 41 & $3.3(1-30)$ & $1.38 \pm 3.4$ & 19 & 2.9 & $0.6 \pm 2.2$ \\
\hline \multicolumn{7}{|l|}{ Acanthocephala } \\
\hline Wolffhugelia matercula & 1.9 & $2(1-3)$ & $0.04 \pm 0.3$ & 2 & 1.3 & $0.02 \pm 0.17$ \\
\hline
\end{tabular}

one intermediate host; four species are allogenic and five autogenic (Tab. I). The autogenic species represents $41 \%$ of the helminths found in SGL and $73 \%$ of helminths found in LL.

Diet. The diet of $O$. bonariensis in both lagoons consisted primarily of microcrustaceans (Copepoda and Cladocera), while others items were rare (Tab. III). However, higher variety of food items was found in the silversides from SGL.

Component community structure. Table IV shows summarized data on helminth component community structure. Silversides from SGL showed higher helminth species richness and diversity compared to those from LL. Evenness was nearly equal for both lagoons, with very low values. The Berger Parker index was higher in LL, due to the high abundance of $C$. macdonaghi that represented $73 \%$ of the total number of helminths.

Infracommunity structure. Table $\mathrm{V}$ shows the results of the analysis of composition of the infracommunities. At site LL, 34\% of the silversides were uninfected, whereas all silversides caught at SGL harbored at least one helminth species. In SGL, individual

Tab. III. Relative frequency of occurrence of food items (FO) in the diet of Odontesthes bonariensis from Salada Grande and Lacombe lagoons.

\begin{tabular}{lcc}
\hline \multicolumn{1}{c}{ Food items } & SGL & LL \\
\hline Microcrustaceans (Cladocera and Copepoda) & $95.9 \%$ & $98.4 \%$ \\
Macrocrustaceans (Palaemonetes argentinus) & $1.8 \%$ & $1.1 \%$ \\
Fishes (Bryconamericus sp. and Astyanax sp.) & $0.7 \%$ & $0.5 \%$ \\
Mollusks (Heleobia parchappei) & $0.8 \%$ & - \\
Ostracods & $0.5 \%$ & - \\
Chironomids larvae & $0.2 \%$ & - \\
Plant parts & $0.1 \%$ & - \\
\hline
\end{tabular}

fish harbored between 1 and 6 (most frequently 4) helminth species, the maximum species richness (9) was not reached, and $A$. cf. mordax was the most abundant species in the infracommunities. In LL, individual fish harbored between 1 and 3 (most frequently 1) helminth species, the maximum richness (5) was not reached, and C. macdonaghi was the most abundant species in the infracommunities.

Host size (standard length) was positively and significantly correlated with helminth species richness, diversity and total abundance, according to Spearman's rank correlation coefficient, with the exception of diversity in SGL (Tab. VI). Helminth species richness, diversity and total abundance were not significantly correlated with sex of the silversides examined (Tab. VI).

Infracommunity diversity $(\mathrm{H})$ was significantly higher in SGL than in LL ( $U=6496, p<0.001)$, even when uninfected individuals were taken into account $(\mathrm{U}=7094, \mathrm{p}<0.001)$.

The seasonal differences in mean values of richness, diversity and number of helminths per

Tab. IV. Comparison of helminth community in Odontesthes bonariensis from Salada Grande and Lacombe lagoons.

\begin{tabular}{lcc}
\hline & SGL & LL \\
\hline Number silversides & 262 & 391 \\
Number helminths & 60978 & 20947 \\
Richness & 9 & 5 \\
H & 0.46 & 0.28 \\
Evenness & 0.15 & 0.12 \\
Dominant species & A. cf. mordax & C. macdonagh \\
\hline Berger Parker index & $49 \%$ & $73 \%$ \\
Autogenic species & 5 & 2 \\
Allogenic species & 4 & 3 \\
\hline
\end{tabular}


infracommunity (Figs 1-3), were not significant $(\mathrm{KW}=1.3, \mathrm{p}=0.7 ; \mathrm{KW}=1, \mathrm{p}=0.8 ; \mathrm{KW}=7, \mathrm{p}=0.43$ in $\mathrm{SGL}$, and $\mathrm{KW}=7, \mathrm{p}=0.43 ; \mathrm{KW}=7.5, \mathrm{p}=0.48 ; \mathrm{KW}=6.9, \mathrm{p}=0.3$ in LL).

\section{DISCUSSION}

Some of the helminth species found are not habitual members of the helminth communities of $O$. bonariensis, but occur regularly in other freshwater fishes from other bodies of water in Buenos Aires Province. These include T. bonariensis, a common parasite of Cichlasoma facetum (Jenyns, 1842) (LuNASCHI, 1988); W. matercula, commonly found as parasite of Cnesterodon decemmaculatus (Jenyns, 1842) and Jenynsia lineata (Jenyns, 1842) (LunAsCHI \& DraGO, 1995), and Saccocoelioides sp., a genus with species reported from numerous freshwater fishes (SzIDAT, 1973; Lunaschi, 1984, 2002; Martorelli, 1986). At the infracommunity level, the presence of these species does not contribute significantly to the evaluation of species

Tab. V. Comparison of helminth infracommunities in Odontesthes bonariensis from Salada Grande and Lacombe lagoons.

\begin{tabular}{lcc}
\hline & $\begin{array}{c}\text { Salada Grande } \\
\text { lagoon }\end{array}$ & Lacombe lagoon \\
\hline Number of silversides & 262 & 391 \\
Richness & $3.59 \pm 1.10$ & $0.95 \pm 0.88$ \\
Mean number of parasites & $233 \pm 409$ & $53.57 \pm 139.17$ \\
$\mathrm{H}$ & $0.31 \pm 0.18$ & $0.04 \pm 0.09$ \\
Evenness & $0.01 \pm 0.005$ & $0.002 \pm 0.01$ \\
Berger-Parker Index & $0.71 \pm 0.19$ & $0.94 \pm 0.12$ \\
Dominant species & A. cf. mordax & C. macdonaghi \\
Uninfected fishes & - & $34.0 \%$ \\
\hline
\end{tabular}

\begin{tabular}{lcc}
\hline \multicolumn{3}{c}{ Percent of coexistent helminth species } \\
\hline 1 species & $3.4 \%$ & $44.0 \%$ \\
2 species & $14.1 \%$ & $14.6 \%$ \\
3 species & $25.2 \%$ & $7.4 \%$ \\
4 species & $36.3 \%$ & - \\
5 species & $19.5 \%$ & - \\
6 species & $1.5 \%$ & - \\
$7,8,9$ species & - & - \\
\hline
\end{tabular}

Tab. VI. Association of richness, $\mathrm{H}$ and number of helminths, with standard length and sex of hosts in Salada Grande and Lacombe lagoons. $\left(r_{\mathrm{s}}=\right.$ values of Spearman's rank correlation coefficient and $\mathrm{U}=$ values of Mann-Whitney test).

\begin{tabular}{ccccc}
\hline & Richness & $\mathrm{H}$ & $\begin{array}{c}\text { Number of } \\
\text { helminths }\end{array}$ \\
\hline \multirow{2}{*}{ SGL } & $\mathrm{r}_{\mathrm{s}}$ & $0,59^{* *}$ & $-0,02 \mathrm{~ns}$ & $0,64 * *$ \\
& $\mathrm{U}$ & $5181 \mathrm{~ns}$ & $4669 \mathrm{~ns}$ & $4900 \mathrm{~ns}$ \\
\hline \multirow{2}{*}{$\mathrm{LL}$} & $\mathrm{r}_{\mathrm{s}}$ & $0,56^{* *}$ & $0,54 * *$ & $0,53^{* *}$ \\
& $\mathrm{U}$ & $7529 \mathrm{~ns}$ & $7785 \mathrm{~ns}$ & $7385 \mathrm{~ns}$ \\
\hline
\end{tabular}

** $\mathrm{p}<0.01$; ns: not significant richness and mean number of individuals due to their low prevalence and abundance (Tab. II). In addition, $W$. matercula and Saccocoelioides sp. do not reach sexual maturity when parasitizing $O$. bonariensis. Similar results were found in the population of Hyphessobrycon meridionalis Ringuelet, Miquelarena \& Menni, 1978 from Saladita lagoon, Buenos Aires Province, where $W$. matercula do not reach sexual maturity, in despite being present throughout the year (DRAGO, 1997).

Helminth assemblages in fish are generally depauperate and isolationist compared with those in endothermic vertebrates; factors such as ectothermy, low vagility and structural simplicity of the gut, among others, have been cited as possible reasons for these differences (KenNedy et al., 1986; KenNedy, 1990). In addition, the freshwater habitats are essentially isolated systems, in which the fish may move more or less freely within them, but natural movements of fish and their parasites between systems necessitates overcoming barriers are thus more limited and infrequent (KENNEDY et al., 1991).

Richness and diversity of helminths of $O$. bonariensis were higher in SGL, despite the smaller sample size in this lagoon. This could be related with several factors: (1) the larger size of SGL and of the silversides collected in this lagoon (significant differences were found between the standard length of silversides from both lagoons; $\mathrm{t}=8.4 ; \mathrm{p}<0.001$ ). The influence of the size of aquatic environments has been discussed by several authors. According to the islandsize hypothesis (island size being defined as the area of an aquatic environment, number of hosts within a population, or the size of an individual host) large islands should contain more parasitic species (Holmes \& PRICE, 1986). Nevertheless, conflicting results have been obtained from this approach (Marcogliese \& Cone, 1991). Some authors have argued that larger areas may sustain larger host populations and thus may favour the existence of higher parasite diversity (KENNEDY, 1978). Moreover, localities with high diversity of host species may be more favourable for parasites with complex life cycles, because of the availability of more definitive host species in which the parasites can achieve full development (GuÉGAN et al., 2005); (2) greater abundance of mollusks and fish-eating birds in SGL, which increases the chances of allogenic species such as, A. (P.) cf. diminuta and Ascocotyle sp.; (3) the greater variety of food items found in the gut of silversides captured in SGL; which increases the chances of autogenic species such as T. bonariensis and Saccocoelioides sp., that were found only in hosts that had gastropods [Heleobia parchappei (d'Orbigny, 1835)] in the gut. The life cycles described for other derogenids and haploporids indicate that fishes become parasitized when they eat infected snails (MARTORELLI, 1986, 1989). 


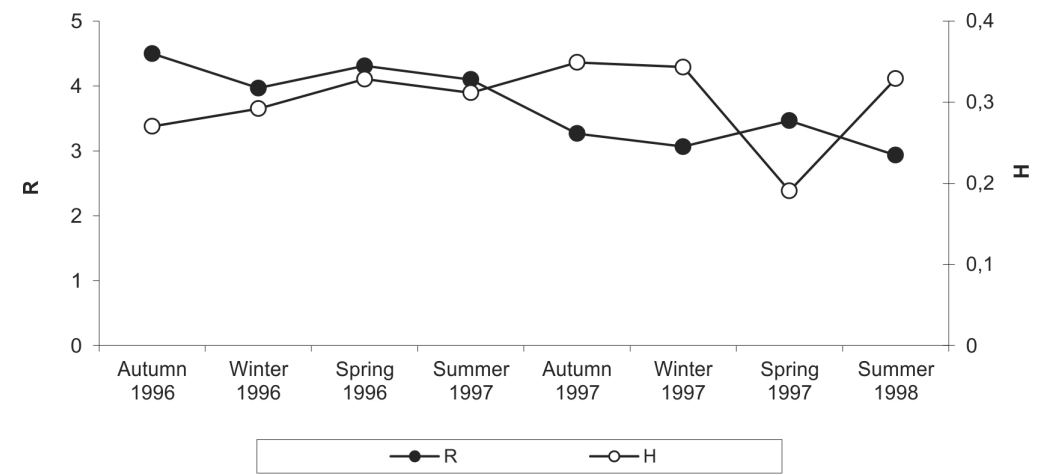

Fig. 1. Seasonal variations of mean richness (R) and mean diversity expressed as Shannon Index (H) per infracommunity in Odontesthes bonariensis (Valenciennes, 1835) from Salada Grande lagoon.

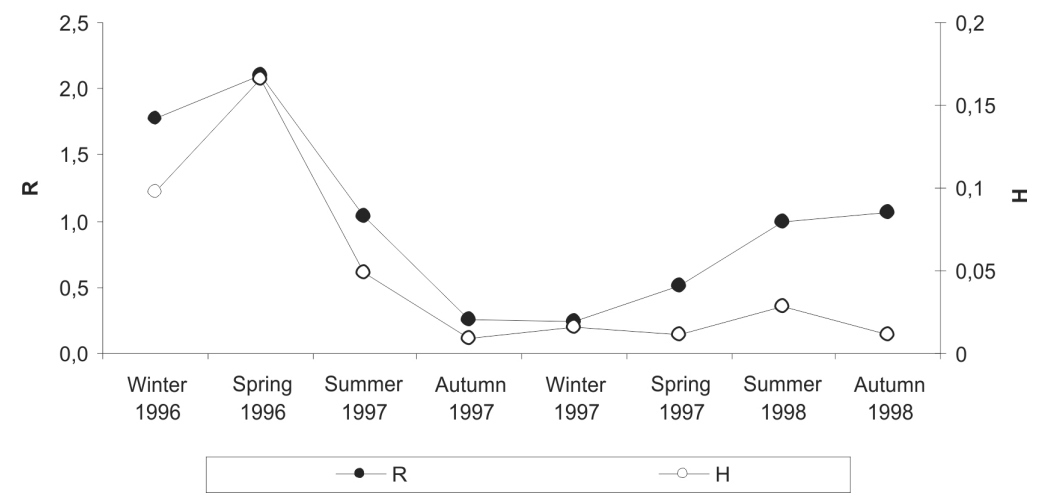

Fig. 2. Seasonal variations of mean richness $(\mathrm{R})$ and mean diversity expressed as Shannon Index $(\mathrm{H})$ per infracommunity in Odontesthes bonariensis (Valenciennes, 1835) from Lacombe lagoon.

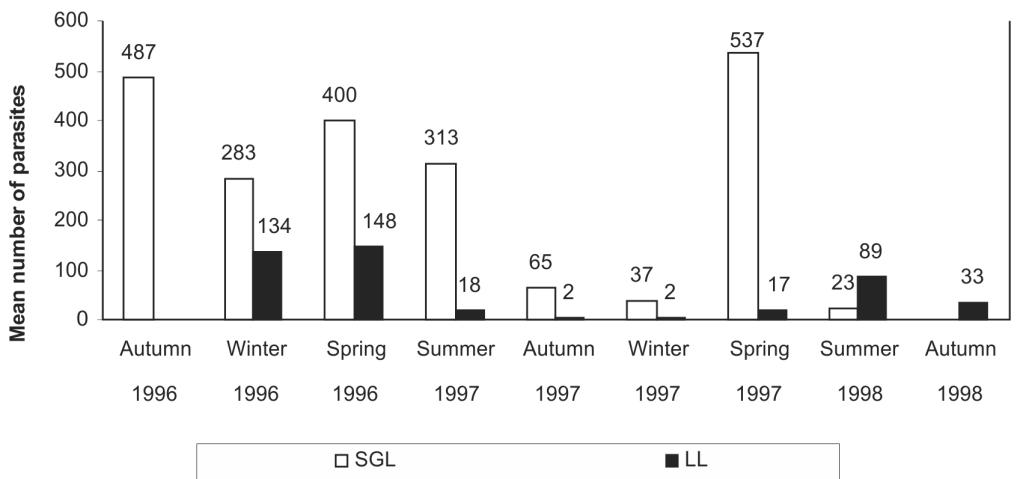

Fig. 3. Seasonal variations of mean number of helminths per infracommunity in Odontesthes bonariensis (Valenciennes, 1835) from Salada Grande and Lacombe lagoons.

The helminth community of silversides is dominated by the autogenic intermediate specialist species C. macdonaghi at the component and infracommunity levels in LL; while it is dominated by the allogenic generalist species $A$. cf. mordax in SGL. Is interesting to note that in LL the dominant species was too the most prevalent, but in SGL the dominant species was not the most prevalent. The specificity of dominant species has been studied in several communities of freshwater fishes; still, no clear pattern has been established because the dominant species may be specialist, generalist, or change across geographic regions for the same host species (KenNedy, 1990, 1995, 1997; SuRes et al., 1999; KenNEdy \& HartVIGSEN, 2000). The allogenic-autogenic condition of dominant species has been analyzed in several opportunities, and in spite of the supposed limitations of autogenic life-style, these species can dominate helminth communities (Esch et al., 1988, Lyndon \& KenNedy, 2001). The differences regarding dominant species in both lagoons suggest that specificity and colonization strategy of silverside parasites do not represent important factors for community dominance. The dominance of the allogenic species $A$. cf. mordax in SGL could be attributed to the greater body size of silversides caught in this lagoon. Moreover, the standard length of silversides from both lagoons has positive correlation with the number of metacercariae of this species $\left(r_{s}=0.8, p<0.001\right.$ in SGL; $\mathrm{r}_{\mathrm{s}}=0.57, \mathrm{p}<0.001$ in LL). 
In some host-parasite systems, community structure may be influenced by host size through changes in diet or volume of ingested food, ontogenetic changes in immunocompetency and changes in the probability of contact with intermediate hosts (Еsch et al., 1990). The higher richness and number of helminths in the infracommunities from larger silversides could be related with the higher variety of food items consumed by these fishes, particularly gastropods and their distribution in the lagoon (larger fish inhabit deep waters while smaller individuals inhabit the coastal region). Moreover, the increased abundance of larval endoparasites in larger fishes can be attributed to the occurrence of cumulative infection processes (IsAac et al., 2000; Guidelli et al., 2003). These processes can explain the increasing number of helminths throughout the life cycle of silversides, especially for larval stages ( $A$. cf. $\operatorname{mordax}, A$. (P.) cf. diminuta, Ascocotyle sp., Hysterothylacium sp. and Contracaecum sp.).

Acknowledgments. Dr. L. Lunaschi, who directed the author's $\mathrm{PhD}$, is gratefully acknowledged. Collection of hosts for scientific research purposes was authorized by "Dirección de Desarrollo Pesquero, Ministerio de Asuntos Agrarios de la provincia de Buenos Aires". The present study was funded by Universidad Nacional de La Plata (UNLP).

\section{REFERENCES}

Bush, A.; Lafferty, K.; Lots, J. \& Shostak, A. 1997. Parasitology meets ecology on its own terms: Margolis et al. Revisited. Journal of Parasitology 83(4):575-583.

Desdevises, Y; Morand, S. \& Legendre, P. 2002. Evolution and determinants of host specificity in the genus Lamellodiscus (Monogenea). Biological Journal of the Linnean Society 77:431-443.

Drago, F. 1997. Dinámica estacional y ecología de las poblaciones de parásitos de Hyphessobrycon meridionalis Ringuelet, Miquelarena \& Menni, 1978 (Pisces-Characidae). Gayana 61(1):15-22.

Escalante, A. 2001. Alimentación natural del pejerrey. In: Grosman, F. ed. Fundamentos biológicos, económicos y sociales para una correcta gestión del recurso pejerrey. Azul, Astyanax. p.69-79.

Esch, G.; Kennedy, C. R.; Bush, A. \& Ано, J. 1988. Patterns in helminth communities in freshwater fishes in Great Britain: alternative strategies for colonization. Parasitology 96:519-532.

Еsсн, G.; Bush, A. \& Ано, J. 1990. Parasite communities, patterns and processes. London, Chapman \& Hall. 335p.

Grosman, F. 2001. Fundamentos biológicos, económicos y sociales para una correcta gestión del recurso pejerrey. Azul, Astyanax. 246p.

Guégan, J. F.; Morand, S. \& Poulin, R. 2005. Are there general laws in parasite community ecology? The emergence of spatial parasitology and epidemiology. In: Thomas, F.; Renaud, F. \& GuÉgan, J. F. eds. Parasitism and Ecosystems. Oxford, Oxford University Press. p.22-42.

Guidelli, G. M.; Isaac, A.; Tакemoto, R. M. \& Pavanelli, G. C. 2003. Endoparasite infracommunities of Hemisorubim platyrhynchos (Valenciennes, 1840) (Pisces: Pimelodidae) of the Baía river, upper Paraná river floodplain, Brazil: Specific composition and ecological aspects. Brazilian Journal of Biology 63(2):261-268.

Holmes, J. \& Price, P. 1986. Communities of parasites. In: KikKawa, J. \& ANDERSON, D. eds. Community ecology: pattern and process. Oxford, Blackwell Scientific Publications, p.187-213.

Isaac, A.; Guidelli, G. M.; Takemoto, R. M. \& Pavanelli, G. C. 2000. Prosthenhystera obesa (Digenea), parasite of Salminus maxillosus (Characidae) of the floodplain of the upper Paraná River, Paraná
Brazil: influence of the size and sex of host. Acta Scientiarum 22(2):523-526.

Kennedy, C. R. 1978. An analysis of the metazoan parasitocoenoses of brown trout Salmo trutta from British lakes. Journal of Fish Biology 13:255-263.

1990. Helminth comunities in fresh water fish: structured communities or stochastic assemblages? In: Esch, G.; Bush, A. $\&$ Ано, J. eds. Parasite communities, patterns and processes. London, Chapman \& Hall. p.131-156.

1995. Richness and diversity of macroparasite communities in tropical eels Anguilla reinhardtii in Queensland, Australia. Parasitology 111:233-245.

1997. Long term and seasonal changes in composition and richness of intestinal communities in eels Anguilla anguilla of an isolated English river. Folia Parasitologica 44:267-273.

Kennedy, C. R.; Bush, A. \& Aно, J. 1986. Patterns in helminth communities: why are fish and birds different? Parasitology 93:205-215.

Kennedy, C. R. \& Hartvigsen, R. 2000. Richness and diversity of intestinal metazoan communities in brown trout Salmo trutta compared to those of eels Anguilla anguilla in their European heartlands. Parasitology 121:55-64.

Kennedy, C. R.; Hartvigsen, R. \& Halvorsen, O. 1991. The importance of fish stocking in the dissemination of parasites throughout a group of reservoirs. Journal of Fish Biology 38:541-552.

LunAschi, L. I. 1984. Helmintos parásitos de peces de agua dulce de la Argentina. I. Tres nuevas especies del género Saccocoelioides Szidat 1954 (Trematoda-Haploporidae). Neotropica 30(83):3142.

. Helmintos parásitos de peces de agua dulce de la Argentina. Tres nuevas especies del género Thometrema Amato, 1968 (Trematoda-Derogenidae). Neotropica 34(91):23-32.

Redescripción de Saccocoelioides octavus Szidat, 1970 y S. bacilliformis Szidat 1973 (Digenea, Haploporidae), parásitos de peces del género Astyanax Baird \& Girard 1854 (Pisces: Characidae). Gayana 66(1):31-37.

Lunaschi, L. I. \& Drago F. B. 1995. Wolffhugelia matercula MañéGarzón \& Dei Cas, 1974 (Neoechinorhynchidae-Gracilisentinae) en peces de la provincia de Buenos Aires, Argentina. Gayana 59(2):109-115.

Lyndon, A. R. \& Kennedy, C. R. 2001. Colonisation and extinction in relation to competition and resource partitioning in acanthocephalans of freshwater fishes of the British Isles. Folia Parasitologica 48:37-46.

Mac Donagh, E. 1932. Sobre una Ichthyotaenia y oncosfera del pejerrey. La semana Médica 25:1-16.

MagurRan, A. E. 1988. Ecological diversity and its measurement. Princeton, Princeton University Press. 179 p.

Mancini, M.; Bucco, C.; Salinas V.; Larriestra, A.; Tanzola, R. \& Guagliardo, S. 2008. Seasonal variation of parasitism in pejerey Odontesthes bonariensis (Atheriniformes, Atherinopsidae) from la viña reservoir (Córdoba, Argentina). Revista Brasileira de Parasitologia Veterinária 17 (1):28-32.

Mancini, M.; Rodriguez, C.; Prosperi, C.; Salinas, V. \& Bucco, C. 2006 Main diseases of pejerrey (Odontesthes bonariensis) in central Argentina. Pesquisa Veterinária Brasileira 26(4):205210.

Marcogliese, D. \& Cone, D. 1991. Importance of lake characteristics in structuring parasite communities of salmonids from insular Newfoundland. Canadian Journal of Zoology 69:2962-2967.

Martorelli, S. 1986. Estudios parasitológicos en biotopos lénticos de la República Argentina III. El ciclo biológico de Saccocoelioides carolae Lunaschi (Digenea) parásito de Cichlasoma facetum (Jenyns, 1842) (Pisces: Cichlidae). Neotropica 32(88):125-132.

Martorelli, S. 1989. Estudios parasitológicos en biotopos lénticos de la República Argentina V. Desarrollo del ciclo biológico monoxeno de la metacercaria progenética de Genarchella genarchella Travassos, 1928 (Digenea, Hemiuridae) parásita de Littoridina parchappei (Mollusca, Hidrobiidae). Revista del Museo de La Plata. Nueva Serie. Zoología 14(157):109117. 
Sures, B.; Knopf, K.; WÜRTZ, J. \& HiRT, J. 1999. Richness and diversity of parasite communities in European eels Anguilla anguilla of the river Rhine, Germany, with special reference to helminth parasites. Parasitology 119:23-330.

SzidAT, L. 1969. Structure, development, and behaviour of new strigeatoid metacercariae from subtropical fishes of south America. Journal of the Fisheries Research Board of Canada 26:753-786.
SzIDAT, L. 1973. Sobre una nueva especie del género Saccocoelioides Szidat, 1954 de Astyanax bipunctatus; Saccocoelioides baciliformis sp. nov., del Río Reconquista, provincia de Buenos Aires. Comunicaciones del Museo Argentino de Ciencias Naturales Bernardino Rivadavia. Parasitología 1:97-100.

Szidat, L. \& NANI, A. 1951 Diplostomiasis cerebralis del pejerrey. Revista del Instituto Nacional de Investigación de las Ciencias Naturales 1(8):323-396.

Recebido em 14 de abril de 2011. Aceito em 27 de março de 2012. ISSN 0073-4721

Artigo disponível em: www.scielo.br/isz 